\title{
REDUKSI DATA PEMERUMAN MENGGUNAKAN TIDAL CONSTITUENT AND RESIDUAL INTERPOLATION (TCARI) (STUDI KASUS: SELAT MAKASSAR)
}

\author{
Duty Kendartiwastra*1, Danar Guruh Pratomo ${ }^{2}$, Eko Yuli Handoko ${ }^{3}$ \\ Departemen Teknik Geomatika FTSLK-ITS, Kampus ITS Sukolilo, Surabaya, 60111 \\ e-mail : *kendartiwastra@gmail.com
}

\begin{abstract}
Abstrak
Koreksi data pemeruman biasanya dilakukan dengan mengurangi nilai kedalaman terhadap tinggi muka air laut yang telah tereferensi terhadap chart datum di waktu yang sama. Faktanya, perbedaan lokasi pemeruman dan pengamatan pasut menyebabkan tinggi muka air laut di kedua tempat tersebut tidak sama dalam waktu yang sama. Hal tersebut terjadi karena adanya perambatan nilai amplitudo dan fase gelombang pasut yang terjadi karena perbedaan karakteristik pasut antara satu wilayah dengan wilayah yang lain. Pembuatan tidal zoning menggunkana metode Tidal Constituent and Residual Interpolation merupakan salah satu solusi untuk permasalahan ini. Kostanta dan residual didapatkan dari data pengamatan 7 stasiun pasut di sekitar Selat Makasssar menggunakan metode least square. Keduanya kemudian diinterpolasi di atas grid yang telah dibobotkan, lalu dihitung menggunakan persaamaan Laplace. Selanjutnya, ekstraksi tinggi muka air laut dilakukan pada zona pemeruman yang terletak 27,752 kilometer dari Stasiun Mahakam. Dengan interval convidence 95\%, menunjukkan bahwa hasil batimetri yang telah terkoreksi oleh tidal zoning dan pengamatan pasut secara langsung memberikan perbedaan yang signifikan.
\end{abstract}

Kata kunci: Koreksi Pemeruman, Zonasi Pasut, TCARI

\section{PENDAHULUAN}

\section{Latar Belakang}

Menurut hasil studi lembaga International Energy Agency (IEA), Indonesia menduduki peringkat 22 sebagai negara penghasil minyak bumi terbesar di dunia dengan produksi mencapai 911000 barrel per hari. Pada tahun 2014 Kementrian ESDM (Energi dan Sumber Daya Mineral) mencatat produksi minyak bumi Indonesia mencapai 7,25 juta barrel per hari, hampir mendekati produksi minyak negara di Timur Tengah. Hal ini membuktikan bahwa Indonesia kaya akan sumber daya minyak dan gas bumi. Bedasarkan peta persebaran area kerja ekploitasi minyak dan gas bumi di Indonesia oleh Direktorat Jendral Migas tahun 2010, salah satu tempat yang banyak dilakukan eksplorasi dan eksploitasi minyak dan gas bumi adalah Selat Makassar. Dalam mendukung kegiatan eksplorasi, eksploitasi dan maintenance bangunan offshore, pada daerah-daerah seperti ini banyak dilakukan kegiatan survei batimetri. Peta batimetri dapat diwujudkan melalui kegiatan pemeruman menggunakan echosounder.

Echosounder digunakan untuk mengukur kedalaman perairan dengan menggunakan gelombang akustik. Gelombang akustik dipancarkan dari transducer kapal secara vertikal ke dasar laut, selanjutnya permukaan dasar laut akan memantulkan kembali pulsa-pulsa itu kemudian diterima oleh transducer kapal. Selang waktu ketika sinyal dipancarkan sampai diterima kembali akan tercatat. Sehingga jarak yang terukur selama selang waktu tersebut merupakan jarak dua kali kedalaman lokal (Xavier 2002).

Kedalaman hasil pengukuran yang didapatkan tetap harus dikoreksi dari berbagai kesalahan yang mungkin terjadi. Kesalahan tersebut dapat berasal dari kecepatan gelombang suara, pasang surut, kecepatan kapal, sistem pengukuran, offset, dan posisi kapal. Dari beberapa sumber kesalahan tersebut, pasang surut air laut merupakan sumber kesalahan utama dalam kegiatan pemeruman, karena efektifitas reduksi data hasil pemeruman pada sebuah chart datum sangat bergantung kepada pemahaman tentang karakteristik pasang surut di suatu wilayah (Wolocot 2008).

Berdasarkan penelitan yang telah ada di Indonesia, sebagian besar metode koreksi hasil pemeruman terhadap pasang surut air laut dilakukan menggunakan data observasi pasang surut dari satu stasiun pasut baik secara real-time atau setelah proses pemeruman dilakukan. Ketinggian muka air laut terhadap chart datum ketika proses pemeruman diasumsikan sama dengan tinggi muka air laut yang tercatat di stasiun pasut terdekat dalam waktu yang sama. Metode seperti ini dinilai kurang akurat dan presisi karena pada kenyatannya, tinggi muka air laut di wilayah 
pemeruman tidak sama dengan tinggi muka air laut yang tercatat di suatu stasiun pasut karena adanya perambatan fase dan amplitudo gelombang pasut. Sehingga perlu adanya pemodelan tidal zoning untuk memprediksi pasut di suatu daerah pemeruman dengan memanfaatkan data pasut dari beberapa stasiun pasut.

Tidal zoning dapat dilakukan menggunakan metode Diskrit atau TCARI (Tidal Constituent and Residual Interpolation). Metode TCARI adalah metode interpolasi pasut dari beberapa stasiun pasut pada suatu grid area pemodelan dengan pembobotan area grid berdasarkan Persamaan LaPlace (Cisternelli 2014). Sehingga setiap titik pada grid memiliki nilai fase dan amplitudo gelombang pasut tertentu yang dapat digunakan untuk membuat prediksi tinggi muka air laut dalam waktu tertentu. Kelebihan TCARI dibandingkan Metode Diskrit adalah dapat menghilangkan diskontinyuitas yang terjadi pada zona transisi, memisahkan perhitungan tinggi muka air akibat efek pasut dan non pasut (cuaca dan river discharge), serta dapat menampilkan uncertainty model akibat perambatan kesalahan Tidal Datum, Astronomic dan Water Level Uncertainty (Cisternelli 2017). Dengan penerapan metode TCARI diharapkan hasil data prediksi pasut dapat lebih akurat dan presisi untuk mengkoreksi hasil pemeruman sehingga didapatkan ketelitian pengukuran kedalaman yang optimal.

\section{METODOLOGI PENELITIAN}

Lokasi penelitian berada di Selat Makassar, dengan koordinat geografis $115^{\circ} 25^{\prime} 3,7^{\prime \prime}$ BT$120^{\circ} 0^{\prime} 34,8^{\prime \prime}$ BT dan $5^{\circ} 30^{\prime} 4,8^{\prime \prime}$ LS- $0^{\circ} 57^{\prime} 52,36^{\prime \prime}$ LU. Lokasi penelitian dan sebaran titik pengamatan pasut dapat dilihat pada Gambar 1. Koordinat geografis dari stasiun pasut dapat dilihat Tabel 1 . Penelitian ini menggunakan pendekatan TCARI untuk melakukan pemodelan zonasi pasut.

Dalam metode TCARI dibutuhkan batas Selat Makassar berupa vektor garis pantai dan informasi lokasi titik stasiun pasut sebagai batas pemodelan. Garis pantai diperoleh dari GSHHG (A Global Self-consistent, Hierarchical, Highresolution Geography Database) yang memiliki resolusi tinggi. Data pengamatan pasut memiliki interval pengamatan 1 jam selama 1 tahun (periode tahun 2017) dan digunakan untuk mengekstrak 11 kostanta pasut serta perhitungan datum vertikal dari setiap stasiun pasut.

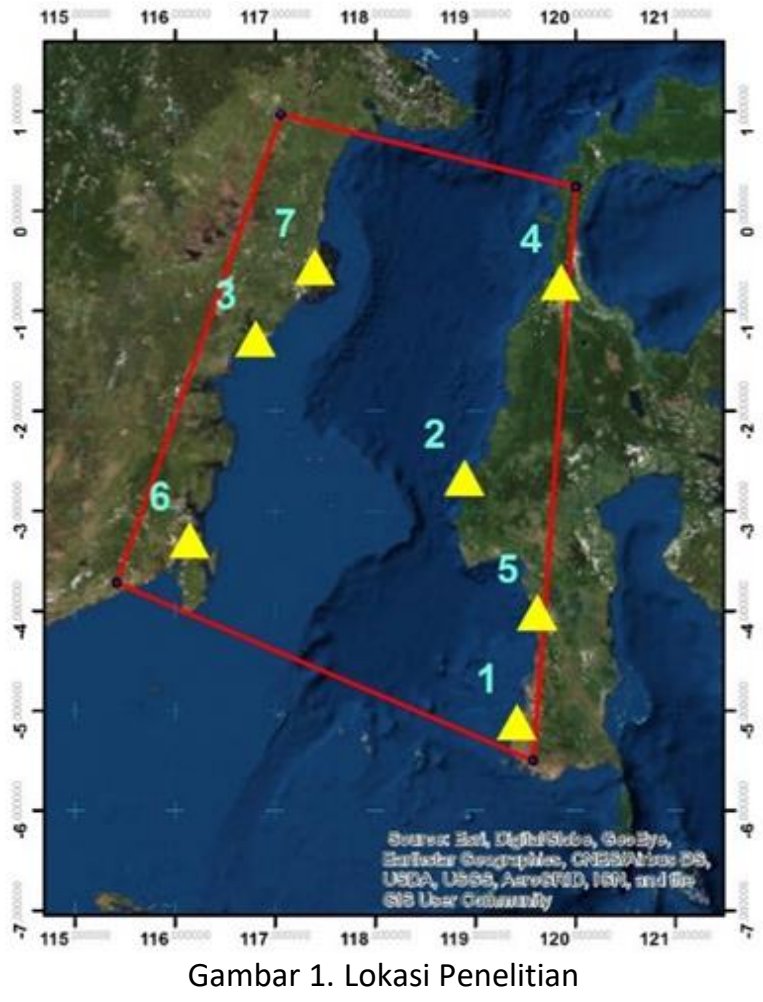

Tabel 1 Stasiun Pengamatan Pasut

\begin{tabular}{clcc}
\hline No & Nama & Lintang $\left(^{\circ}\right)$ & Bujur $\left(^{\circ}\right)$ \\
\hline 1 & Makassar & $-5,112$ & 119,418 \\
\hline 2 & Mamuju & $-2,667$ & 118,893 \\
\hline 3 & Balikpapan & $-1,272$ & 116,806 \\
\hline 4 & Pantoloan & $-0,712$ & 119,857 \\
\hline 5 & Pare-pare & $-4,014$ & 119,620 \\
\hline 6 & Kotabaru & $-3,291$ & 116,146 \\
\hline 7 & Delta Mahakam & $-0,553$ & 117,399 \\
\hline
\end{tabular}

Tahapan pengolahan data yang dilakukan pada penelitian ini akan dijelaskan sebagai berikut:

\section{Ekstraksi Kostanta Pasut Observasi}

Data observasi pasang surut air laut dari titik-titik stasiun pasut diolah dengan metode kuadrat terkecil untuk mendapatkan 11 konstituen pasut (M2, S2, N2, K2, K1, O1, P1, MF, MM, M4, dan MS4). Konstituen tersebut selanjutnya digunakan untuk memprediksi pasut di masing-masing titik. Dengan mencari selisih antara data observasi dan prediksi, didapatkan residu. Di mana residu ini merupakan nilai yang mewakili parameter pengaruh komponen non pasut seperti river discharge dan pengaruh cuaca.

Nilai observasi, prediksi, dan residu berfungsi sebagai data input untuk melakukan interpolasi dan pembobotan berdasarkan persamaan Laplace. Variasi naik turunnya muka air laut adalah hasil 
penjumlahan (superposisi) dari semua gelombang komponen harmonik pasut yang terjadi.

\section{Pembuatan Model Zonasi Pasut}

Model dibangun dengan menggunakan perangkat lunak Pydro. Domain model dibuat dengan mempertimbangkan batas area pemodelan berupa vektor garis pantai yang mengelilingi Selat Makassar dan koordinat satsiun pasut yang telah ditentukan sebelumnya. Setelah area pemodelan telah ditentukan, selanjutnya dilakukan proses griding menggunakan metode TIN (Triangular Interpolation Network).

Data hasil pengolahan berupa 11 konstituen pasut dan data observasi pasut di masing-masing titik digunakan sebagai data input untuk melakukan pembobotan dan interpolasi berdasarkan persamaan Laplace pada model grid yang telah dibuat.

Dalam metode TCARI digunakan persamaan Laplace sebagai dasar interpolasi amplitudo dan fase dari setiap kostanta pasut dari setiap stasiun pasut ke titik-titik hasil griding. Menurut Kurt Hess (2004) persamaan Laplace adalah sebagai berikut:

$\frac{\partial G}{\partial x^{2}}+\frac{\partial G}{\partial y^{2}}=0$

$G\left(x_{m}, y_{m}\right)=G_{m}^{0}$

Dimana $m$ adalah indeks dari stasiun-stasiun pasut yang digunakan, sedangkan $G$ adalah nilai yang diketahui pada satu titik dan $\mathrm{x}, \mathrm{y}$ adalah posisi dari titik yang ingin diketahui nilainya. Dalam rangka mempercepat proses komputasi dan ruang penyimpanan, dilakukan penyederhanaan rumus Laplace yang dapat dilihat pada rumus berikut.

$$
\begin{aligned}
& G(x, y)=\sum_{m=1}^{M} g(x, y, m) G_{m}^{0} \\
& \frac{\partial g}{\partial x^{2}}+\frac{\partial g}{\partial y^{2}}=0 \\
& g\left(x_{i}, y_{i}, m\right)=\delta_{m}
\end{aligned}
$$

\section{Ekstraksi Tinggi Muka Air Laut}

Kostanta pasut yang terinterpolasi pada daerah pemodelan, kemudian digunakan untuk ekstraksi tinggi muka air laut (water level). Setelah itu dilakukan perbanddingan untuk mengetahui

perbedaan pola dan nilai tinggi muka air laut di salah satu titik pemodelan terhadap pola pasut di stasiun pengamatan pasut terdekat.

Variasi tinggi muka laut di suatu tempat dapat dinyatakan sebagai superposisi dari berbagai komponen harmonik pasang surut. Dengan demikian tinggi muka air pada suatu saat $t_{n}$ dapat dituliskan dalam persamaan (2.5) (Emery 1998):

$x\left(t_{n}\right)=\bar{x}+\sum_{q=1}^{M} C_{q} \cos \left(2 \pi f_{q} t_{n}-\emptyset_{q}\right)$ dimana:

$x\left(t_{n}\right)=$ tinggi muka air pada waktu $t_{n}$

$\bar{x}=$ tinggi muka air rata-rata dari suatu referensi yang ditentukan

$C_{q}$ =amplitudo komponen pasut di tempat pengamatan

$f_{q}=$ frekuensi dari gelombang tiap komponen pasut

$\emptyset_{q}$ =fase gelombang komponen pasut pada $\mathrm{t}=0$

$M=$ jumlah komponen pasut pembentuk superposisi

\section{Pengolahan Data Pemeruman}

Data pemeruman diolah berdasarkan 2 skema. Pada skema 1 data pemeruman dikoreksi menggunakan pasut pengamatan, sedangkan pada skema ke-dua, data pemeruman dikoreksi menggunakan pasut hasil prediksi TCARI. Kedua model batimetri yang dihasilkan dari masingmasing skema diuji tingkat signifikannya menggunakan Uji Z.

Uji Z dalam penelitian ini menggunakan uji hipotesis dua arah untuk mengetahui apakah kedua sampel memiliki proporsi yang sama atau tidak. Berdasarkan nilai $Z_{0}$ hasil perhitungan selanjutnya dibandingkan dengan nilai $Z$ tabel dengan tingkat kepercayaan 95\%, tingkat kepercayaan $95 \%$ memiliki tingkat signifikansi sebesar $5 \%$ atau 0,05 . Nilai $Z$ tabel dengan tingkat signifikansi $5 \%$ pada uji hipotesis dua arah adalah 1,96 .

\section{HASIL DAN PEMBAHASAN}

\section{Ekstraksi Kostanta Pasut}

Berdasarkan proses peengolahan data observasi di tujuh stasiun pengamatan pasut didapatkan dua daerah yang memiliki tipe dan pola 
pasut yang mempunyai perbedaan signifikan, yaitu stasiun Makassar dan Delta Mahakam. Nilai kostanta di dua astasiun tersebut ditunjukkan oleh Tabel 2 dan Tabel 3. Pola tipe pasut di stasiun Makassar adalah (pasut campuran condong harian tunggal) sedangkan tipe pasut di stasiun Delta Mahakam adalah (pasut campuran condong harian ganda). Kedua perbedaan pola tersebut terlihat jelas pada Gambar 2 dan Gambar 3.

Tabel 2 Kostanta Pasut Stasiun Makassar

\begin{tabular}{|c|c|c|c|}
\hline NOMOR & KOSTANTA & AMPLITUDO $(\mathbf{c m})$ & $\begin{array}{c}\text { FASE } \\
(\boldsymbol{\%})\end{array}$ \\
\hline $\mathbf{1}$ & M2 & 11,434 & $-80,661$ \\
$\mathbf{2}$ & S2 & 15,281 & $-32,460$ \\
$\mathbf{3}$ & N2 & 2,705 & 79,662 \\
$\mathbf{4}$ & K2 & 6,062 & 105,686 \\
$\mathbf{5}$ & K1 & 28,343 & 174,761 \\
$\mathbf{6}$ & O1 & 17,284 & $-129,179$ \\
$\mathbf{7}$ & P1 & 10,845 & 174,511 \\
$\mathbf{8}$ & Mf & 0,899 & 162,982 \\
$\mathbf{9}$ & Mm & 1,773 & 73,108 \\
$\mathbf{1 0}$ & M4 & 0,590 & $-63,277$ \\
$\mathbf{1 1}$ & MS4 & 0,398 & $-139,023$ \\
$\mathbf{1 2}$ & S0 & 123,579 & \\
\hline
\end{tabular}

Tabel 3 Kostanta Pasut Stasiun Makassar

\begin{tabular}{|c|c|c|c|}
\hline NOMOR & KOSTANTA & AMPLITUDO $(\mathbf{c m})$ & $\begin{array}{c}\text { FASE } \\
(\mathbf{})\end{array}$ \\
\hline $\mathbf{1}$ & M2 & 64,153 & $-118,056$ \\
$\mathbf{2}$ & S2 & 45,727 & $-139,923$ \\
$\mathbf{3}$ & N2 & 8,156 & 117,422 \\
$\mathbf{4}$ & K2 & 15,542 & $-10,948$ \\
$\mathbf{5}$ & K1 & 22,946 & $-72,807$ \\
$\mathbf{6}$ & O1 & 15,591 & $-29,205$ \\
$\mathbf{7}$ & P1 & 9,409 & $-70,589$ \\
$\mathbf{8}$ & Mf & 2,081 & 109,262 \\
$\mathbf{9}$ & Mm & 2,569 & 142,647 \\
$\mathbf{1 0}$ & M4 & 2,141 & $-73,247$ \\
$\mathbf{1 1}$ & MS4 & 0,992 & 171,378 \\
$\mathbf{1 2}$ & S0 & 157,817 & \\
\hline
\end{tabular}

\section{Hasil Griding dan Pembobotan}

Proses griding menggunakan metode TIN (triangular interpolation network) menghasilkan 9900 titik dengan luas area Selat Makassar sekitar 255268,763 kilometer persegi. Titik-titik tersebut akan semakin rapat pada wilayah yang dekat dengan garis pantai dan batas pulau. Hal ini dapat ditunjukkan oleh Gambar 2. Variasi kerapatan titik hasil griding tersebut mengindikasikan bahwa proses komputasi akan semakin sering dilakukan di titik-titik yang dekat dengan garis pantai dan batas pulau. Metode seperti ini baik untuk digunakan, mengingat geometri pantai, teluk dan tanjung juga berpengaruh terhadap efek lokal seperti angin dan arus yang secara tidak langsung mempengaruhi karakter atau tipe pasut di suatu wilayah.

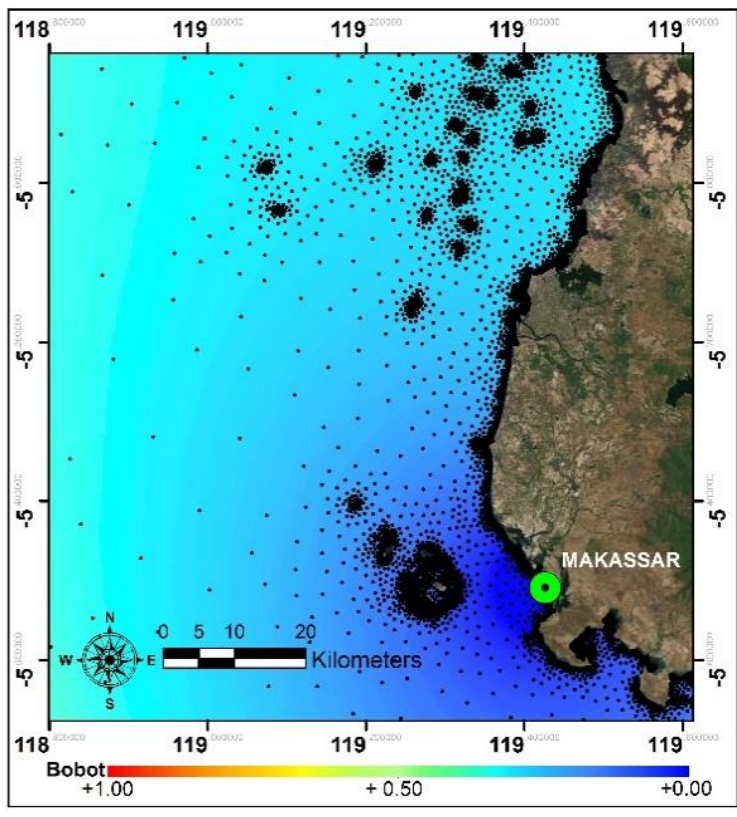

Gambar 2. Hasil Griding Di Sekitar Stasiun Pasut Makassar

Pada proses selanjutnya, nilai kostanta dan fase dari setiap stasiun pasut yang telah diketahui, diinterpolasi menggunakan persamaan Laplace yang teriterasi pada setiap titik hasil proses griding. Untuk mempercepat iterasi dan efektifitas ruang penyimpanan (memori), digunakan formula hasil penyederhanaan persamaan Laplace. Dalam formula ini dibutuhkan weighted field yang diperoleh dari proses pembobotan. Proses pembombotan dilakukan berdasarkan formula boundary condition. Hasil pembobotan mempunyai rentang 0 sampai 1 . Semakin jauh dari stasiun pasut, maka nilainya akan mendekati 1 , artinya data prediksi yang dihasilkan akan lebih akurat ketika radius tempat tersebut ke titik pengamatan pasut semakin kecil. Sehingga secara tidak langsung rentang tersebut dapat menunjukkan tingkat ketidakpercayaan (uncertainty) dari model pasut yang telah dibuat seperti pada Gambar 3. 


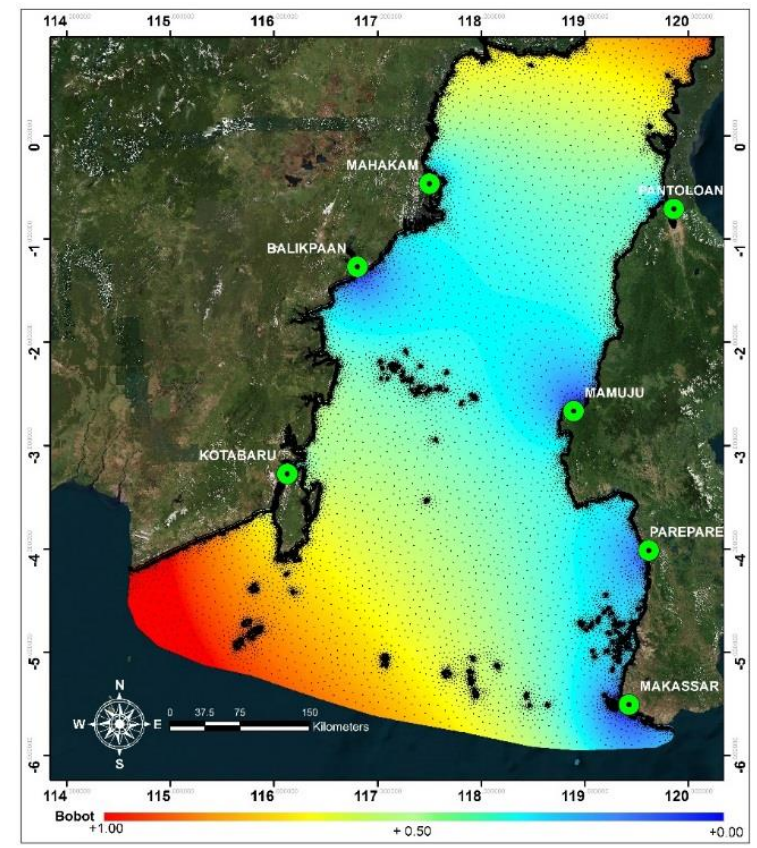

Gambar 3 Hasil Griding dan Pembobotan

Stasiun Pasut Mahakam dan Pantoloan kurang memberikan kontribusi tingkat kepercayaan terhadap model karena letaknya yang terlalu menjorok ke darat dan berada pada sebuah delta sungai. Stasiun Pasut Kotabaru yang terhalang oleh Pulau Laut, juga kurang memberikan efek yang baik terhdap model yang dihasilkan. Sehingga wilayah bagian selatan Kotabaru mempunyai tingat uncertainty yang tinggi, ditunjukkan oleh warna merah yang lebih dominan.

\section{Co-Tidal}

Kostanta pasut yang telah diinterpolasi berdasarkan metode TCARI dapat dianalisa dengan melihat hasil Co-tidal yang dihasilkan. Dari 11 kostanta pasut yang dimodelkan, terdapat 3 kostanta yang mengalami beberapa anomali nilai amplitudo, yaitu konstanta M4, O1, dan P1. Anomali pada konstanta M4 dapat dilihat pada Gambar 4.

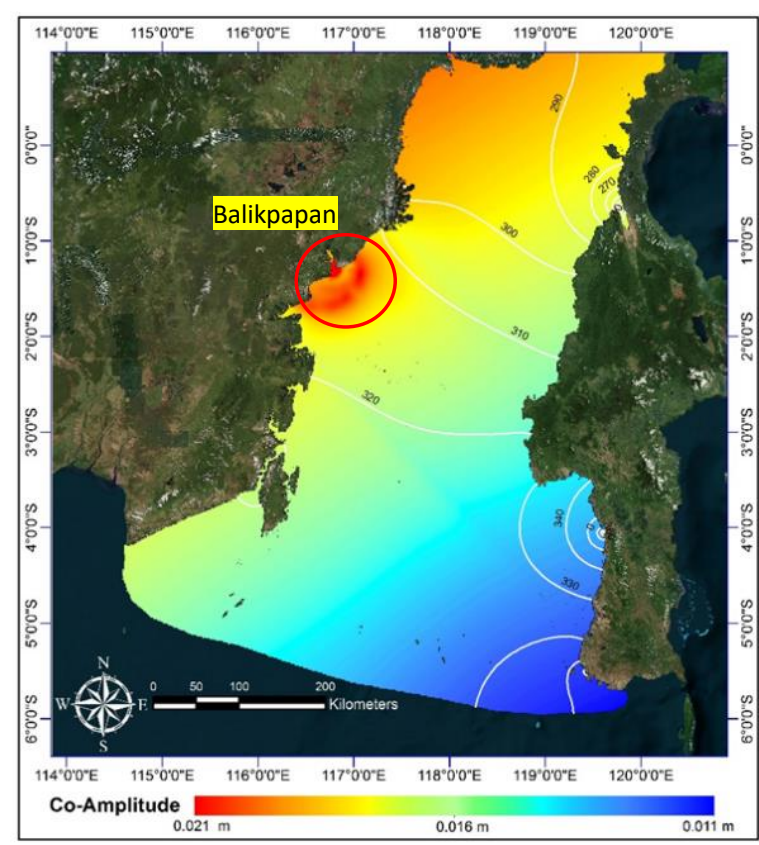

Gambar 4 Co-Tidal M4

Perambatan amplitudo M4 terjadi dari bagian selatan Selat Makassar menuju ke arah utara (Samudra Pasifik). Anomali nilai amplitudo M4 terjadi di sekitar pesisir Balikpapan. Kostanta pasut M4 merupakan kostanta periode dangkal, yaitu konstanta pasang surut yang terbentuk karena adanya distorsi non-linear dari osilasi kostanta pasang surut utama pada saat berinteraksi dan merambat di perairan dangkal.

Terdapat dua penyebab utama terbentuknya konstanta ini, pertama akibat gesekan dasar serta proses fisis yang bergantung pada nilai kuadrat amplitudonya, kedua akibat proses hidrodinamika, kedua penyebab tersebut merupakan komponen non-linear. Selain kedua hal diatas, penyebab lainnya adalah efek resonansi lokal dan pembentukan gelombang stasioner (Basith 2015). Anomali nilai amplitudo di pesisir Balikpapan ini dimungkinkan terjadi karena geometri garis pantai pesisir Balikpapan tidak teratur, dibuktikan oleh adanya beberapa teluk, seperti Teluk Balikpapan, Teluk Apar dan Teluk Adang yang menyebabkan terjadinya resonansi pada osilasi gelombang pasut utama yang kemudian memberikan efek anomali nilai amplitudo M4 seperti yang ditunjukkan oleh Gambar 5. 


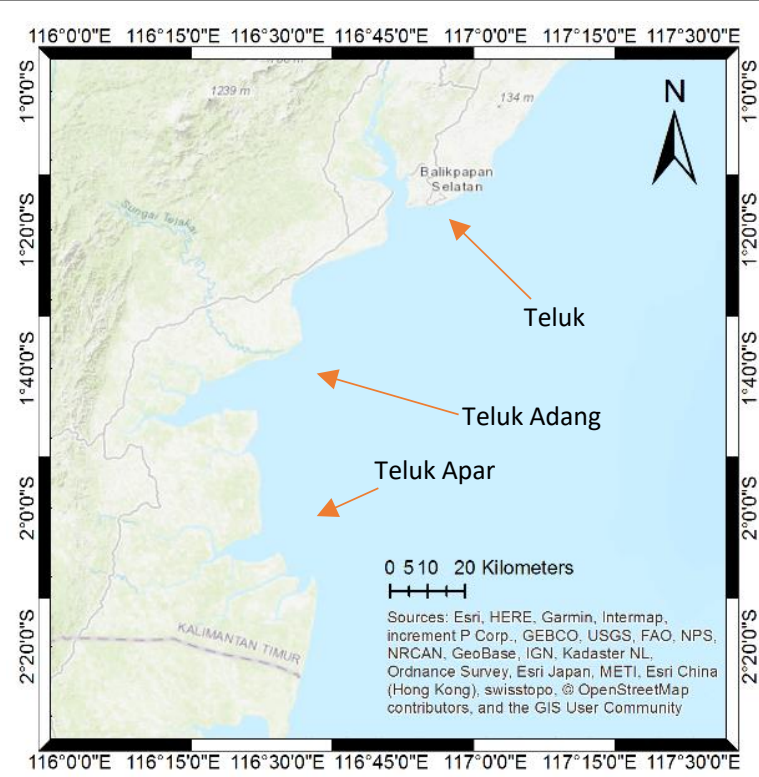

Gambar 5. Geometri Pesisir Balikpapan

Kostanta pasut $\mathrm{O} 1$ merupakan kostanta yang dipengaruhi oleh gravitasi bulan (Principal lunar diurnal), anomali nilai amplitudo di bagian selatan pesisir Kotabaru terjadi karena adanya Pulau Laut dan Pulau Kalimantan yang membentuk suatu kanal kecil yang bertindak sebagai resonator seerti yang ditnjukan oleh Gambar 6. Respon perairan yang sebagian tertutup spserti teluk terhadap gaya pembangkit pasut laut yang masuk dipengaruhi oleh natural modes dan resonansinya terhadap periode pasut (Ali 1994).

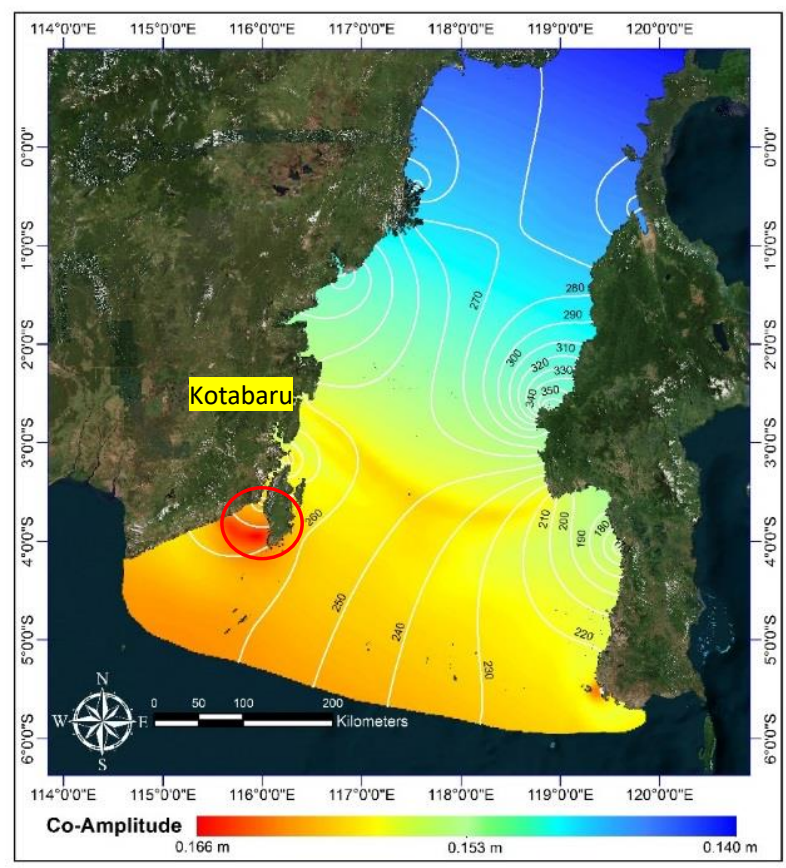

Gambar 6. Co-Tidal 01
Anomali nilai amplitudo P1 (Gambar 7) di peisisr Makassar dimungkinkan terjadi karena perbedaan kedalaman yang terlalu drastis antara paparan Kepulauan Pabbiring dan laut lepas yang mengarah ke Laut Jawa seperti yang ditunjukkan pada Gambar 7.

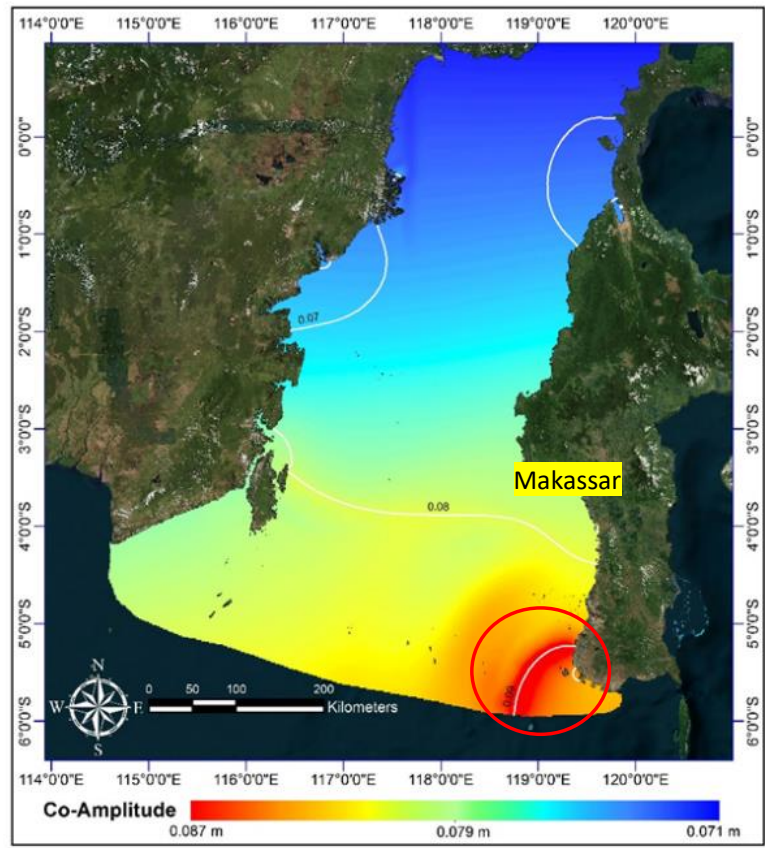

Gambar 7. Co-Tidal P1

Menurut Ali (2004) menjelaskan bahwa di daerah seperti ini pasut (elevasi dan arus pasut) mengalami perubahan jika dibandingkan dengan perairan dalam. Magnitudonya bertambah, kadang-kadang dengan faktor yang besar jika terjadi resonansi antara periode pasut dan periode natural. Arus pasut di perairan kontinental shelf menjadi lebih besar. Selain itu, jika gerakan pasut yang dibangkitkan di laut lepas menjalar sebagai gelompang ke kontinental slope dan shelf atau perairan pantai, maka gelombang pasut tersebut akan mengalami perubahan akibat berkurangya

\section{Ekstraksi Water Level}

Ekstraksi tinggi muka air laut (water level) dilakukan pada lokasi di mana kegiatan pemeruman dilakukan. Stasiun pasut yang digunakan untuk pengamatan tinggi muka air laut ketika pemeruman dilakukan adalah stasiun Delta Mahakam. Sehingga nilai prediksi muka air laut di lokasi pemeruman akan dibandingkan dengan nilai pengamatan muka air laut di stasiun pengamatan Delta Mahakam untuk kemudian digunakan dalam proses koreksi data pemeruman skema $\mathrm{A}$ dan 
skema B. Kegiatan Pemeruman dilakukan pada tanggal 24, 25, dan 26 September 2017.

Prediksi nilai muka air laut diekstrak dengan interval waktu 10 menit dengan harapan dapat digunakan untuk mereduksi data pemeruman secara lebih teliti. Nilai perbedaan tinggi muka air laut maksimum, minimum dan rata dari grafik di atas, ditunjukkan oleh Tabel 4. Jarak antara lokasi pengamatan dan lokasi pemeruman kurang lebih sekitar $27 \mathrm{~km}$.

Tabel 4 Selisih Water Level Lokasi Pengamatan Pasut dan Pemeruman

\begin{tabular}{|c|c|c|c|}
\hline Selisih & $\mathbf{2 4 - 0 9 - 2 0 1 7}$ & $\mathbf{2 5 - 0 9 - 2 0 1 7}$ & $\mathbf{2 6 - 0 9 - 2 0 1 7}$ \\
\hline Maksimum & 0,926 meter & 0,592 meter & 0,514 meter \\
\hline Minimum & 0,003 meter & 0,011 meter & 0,246 meter \\
\hline Rata-rata & 0,394 meter & 0,313 meter & 0,395 meter \\
\hline
\end{tabular}

Perbedaan tinggi muka air laut antara lokasi pengamatan pasut dan lokasi pemeruman terjadi karena pola pasut yang berbeda pada kedua tempat tersebut. Hal ini dibuktikan oleh pola pasut di kedua tempat tersebut selama 3 hari. Meskipun tidak terlalu besar, namun efek yang ditimbulkan dalam proses koreksi kedalaman untuk pembuatan batimetri mempunyai perbedaan sangat signifikan.

\section{Hasil Pengolahan Data Pemeruman}

Kegiatan pemeruman dilakukan di sekitar delta Sungai Mahakam pada tanggal 24, 25, dan 26 September 2017. Berdasarkan standar IHO, kriteria daerah survei masuk ke dalam orde spesial dengan total vertical uncertainty yang diperbolehkan adalah $95 \%$ confidence level dengan nilai a $=0.25$ dan $b=0,0075$. Lokasi pemeruman terletak di sekitar koordinat $0,706^{\circ} \mathrm{LS}$. Pemeruman dilakukan menggunakan R2Sonic dengan luas area pemeruman sekitar $147212,436 \mathrm{~m}^{2}$, terdiri dari 48 lajur utama dan 5 lajur silang.

Pengolahan data pemeruman dilakukan melaui koreksi spike, kecepatan suara (SVP), draft kapal dan patch test (roll, pitch, dan yaw). Setelah terkoreksi oleh beberapa parameter tersebut, data pemeruman dikoreksikan terhadap pasut menggunakan 2 skema. Skema 1 data pemeruman dikoreksi menggunkan pasut pengamatan, sedangkan pada skema 2 data pemeruan dikoreksi menggunakan pasut hasil prediksi TCARI.
Pada skema 1 hasil rata-rata kedalaman yang telah terkoreksi pasut adalah 2,833 meter, maksimum 12,656 meter dan minimum 0,938 meter. Bentuk dasar laut cenderung datar tetapi ada beberapa pattern yang mengindikasikan beberapa lubang bekas tancapan platform seperti pada Gambar 8 . Terdapat anomali spike pada daerah nadir sehingga menyebabkan pola garis pada setiap line tetapi dapat diminimalisir dengan pembersihan spike, meskipun tidak sepenuhnya hilang.

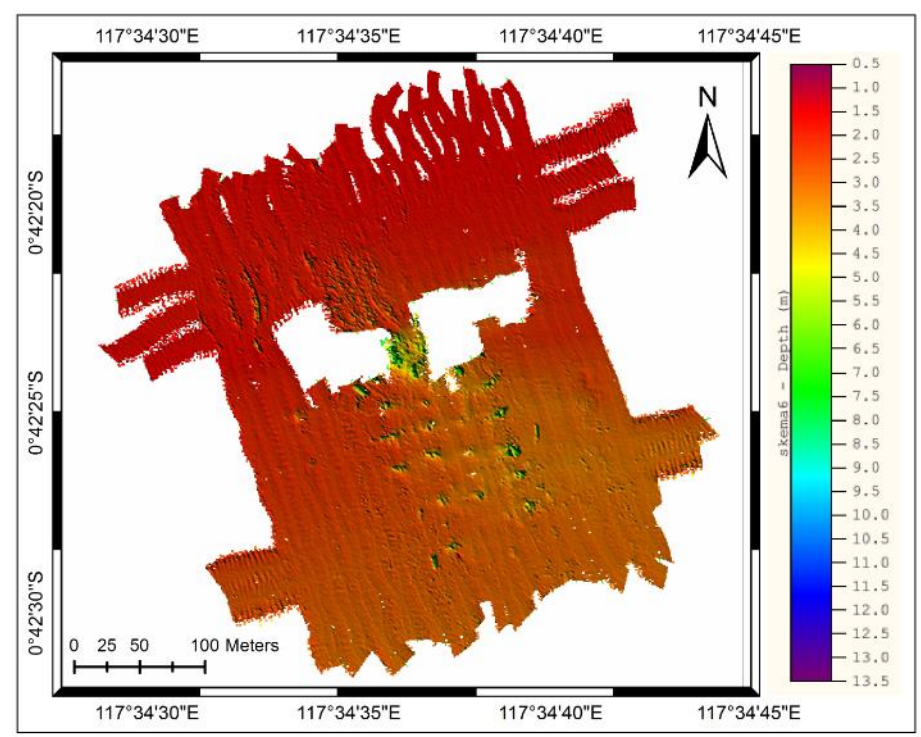

Gambar 8 Hasil Reduksi Data Pemeruman Skema 1

\section{Skema 2}

Pada skema 2 hasil rata-rata kedalaman yang telah terkoreksi pasut adalah 3,675 meter, maksimum 13,585 meter dan minimum 0,556 meter. Dari rona warna yang ditampilkan oleh Gambar 8 dapat diketahui bahwa bentuk dasar laut cenderung lebih memiliki kemiring yang curam daripada hasil skema 1. Selain itu, pattern beberapa lubang bekas tancapan platform juga terlihat lebih jelas.

Pola dasar laut seperti lipatan di daerah yang lebih dangkal dimungkinkan terjadi karena Motion Reference Unit (MRU) yang digunkan tidak compatible dengan arus yang terjadi di daerah pemeruman. Hal ini terjadi baik pada skema 1 dan 2. Meskipun hasil perbedaan nilai waterlevel yang telah dibahas pada sub bab sebelunya cukup kecil, dapat dilihat bahwa koreksi pasut memberikan efek yang signifikan terhadap batimetri yang dihasilkan.

\section{Skema 1}




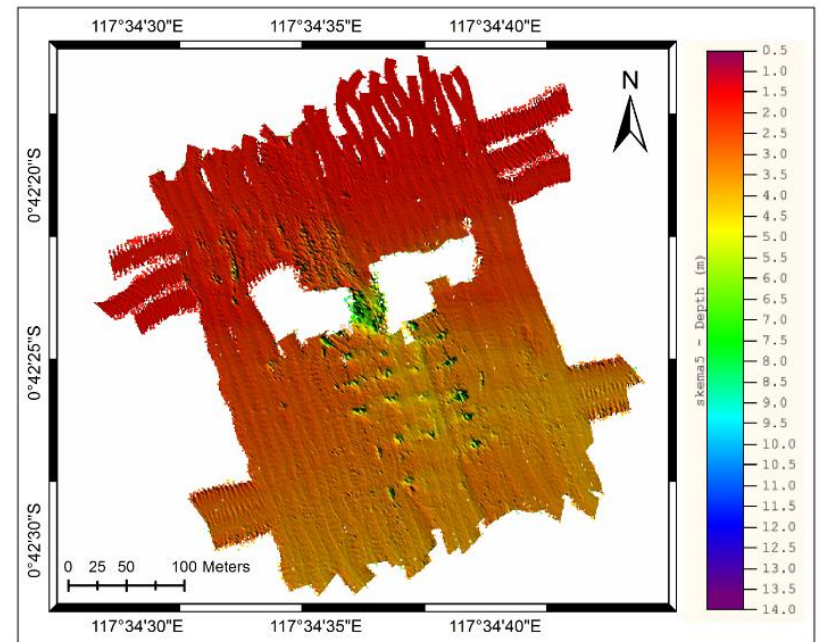

Gambar 10 Hasil Reduksi Data Pemeruman Skema 2

\section{Hasil Uji Signifikansi Pemeruman Skema 1 dan Skema 2}

Batimetri hasil skema 1 dan 2 dapat diketahui tingkat signifikansi dengan melakukan uji $Z$ terhadap kedua model. Uji Z dilakukan dengan cara mengambil beberapa sampel kedalaman pada hasil batimeri skema 1 dan 2 berdasarkan titik ICP. Jumlah titik ICP adalah sebanyak 259 titik yang telah tersebar merata di seluruh lokasi pemeruman.

Nilai maksimum, minimum, standar deviasi, dan varian data kedalaman pada model batimetri skema 1 dan skema 2 ditunjukan oleh Tabel 4 . Nilainilai tersebut digunakan untuk menentukan zona kritis yang diperbolehkan agar kedua model dapat dikatakan sama $(\mu 1=\mu 2)$.

Pada pengolahan data kedalaman hasil batimetri skema 1, didapatkan nilai rata-rata kedalaman 2,833 meter, nilai maksimum dan minimum berturut-turut 4,544 meter dan 0,395 meter. Varian data kedalaman pada 259 titik ICP skema 1 adalah 0,395 meter, dengan standar deviasi sebesar 0,629 meter. Sedangkan hasil pengolahan data kedalaman pada skema 2 diperoleh rata-rata kedalaman sebesar 3,675 meter, serta nilai maksimum dan minimum kedalaman berturutturut 6,431 meter dan 2,347 meter. Variasi data kedalaman pada skema 2 adalah 0,429 meter, dengan standar deviasi sebesar 0,655 meter.

Dengan tingkat kepercayaan $95 \%$ atau 0,05 level of significant menunjukkan bahwa rata-rata kedalaman skema 1 tidak sama dengan rata-rata kedalaman skema 2. Hal ini dibuktikan oleh nilai Z hasil hitungan sebesar 14,924, sedangkan interval zona kritis yang diperbolehkan adalah $-1,96 \leq \mathrm{Z} \leq$
1,96. Sehingga hipotesa $\mu 1=\mu 2$ ditolak (rejected) dan yang digunakan adalah hipotesa alternatif yaitu bahwa $\mu 1 \neq \mu 2$.

\section{KESIMPULAN}

Pemodelan Tidal Zoning dilakukan dengan cara pembuatan batas pemodelan yang di-griding untuk mendapatkan titik-titik pemodelan. Titik-titik tersebut kemudian akan digunakan dalam proses komputasi berdasarkan persamaan Laplace. Dibutuhkan field bobot untuk sebagai solusi untuk melakukan persamaan Laplace yang nilainya bergantung pada boundary condition. Hasil akhir dari proses pembuatan tidal zoning dinyatakan dalam Co-Tidal yang dapat menampilkan perambatan amplitudo dan fase dari setiap kostanta pasut yang dimodelkan. Sehingga masingmasing titik grid dapat diketahui tinggi muka air lautnya berdasarkan formula perhitungan water level.

Dengan menggunakan tidal zoning, tinggi muka air laut di waktu, posisi dan interval serta jangka waktu pengamatan tertentu dapat diketahui. Nilai tinggi muka air laut ini dapat digunakan untuk melakukan reduksi data pemeruman. Untuk mengetahui perbedaan hasil pemeruman yaang dikoreksi dengan metode TCARI dan metode pengamatan pasut pada umumnya, dilakukan uji coba menggunakan 2 skema. Skema ke-1 digunakan data prediksi dari 1 stasiun pasut, sedangkan skema ke-2 dilakukan dengan menggunakan data prediksi hasil TCARI. Dengan level of signifikan sebesar $5 \%(0,05)$, kedua skema ini menujukkan perbedaan yang signifikan. Dengan demikian, metode TCARI dinilai efektif dalam mengatasi tidal zoning error untuk melakukan prediksi water level sebagai reduksi data pemeruman.

\section{DAFTAR PUSTAKA}

Ali, M., Hadi, S., \& Mihardja, D. K. (1994). Pasang Surut Laut. Bandung: Institut Teknologi Bandung.

Basith, A., \& Prakoso, Y. (2015). Kontribusi Kostanta Pasang Surut Perairan Dangkal.

Cisternelli, M., \& Martin, C. (n.d.). A Comparison of Discrete Tidal Zoning and Tidal Constituent and Residual Interpolation (TCARI) Methodologies For Use in Hydrographic Sounding Reduction.

Hess, K., Schmq, R., Zervqs, C., \& Collier, W. (2004). Tidal Constituent and Residual Interpolation 
(TCARI): A NewMethodfor theTidolCorrectionof

Bothymetric Doto. US: NOAA.

Wolocot, D. (2008). Standar Operation Procedur of

TCARI. America: NOAA.

Xavier, L. (2002). An Introduction to Underwater

Acoustic. United Kingdom: Praxis Publishing. 